\title{
PENERAPAN MODEL PEMBELAJARAN KONTEKSTUAL DENGAN MENGGUNAKAN MEDIA FACEBOOK DALAM PEMBELAJARAN MENULIS PUISI PADA SISWA SMP
}

\author{
Miftakhul Maulidiyah ${ }^{1}$, Riskha Arfiyanti ${ }^{2}$, Mudopar ${ }^{3}$ \\ Universitas Swadaya Gunung Jati Cirebon \\ Lidya92@ymail.com, riskhaarfiyanti@unswagatai.ac.id \\ mudopar@unswagati.ac.id
}

\begin{abstract}
ABSTRAK
Dalam pembelajaran menulis puisi siswa diharapkan mampu menghasilkan sebuah karya yang indah dan bermakna sehingga membuat pendengar atau pembaca merasakan apa yang dirasakan oleh pengarang. Namun, proses penciptaan puisi masih menjadi hambatan bagi siswa. Oleh karena itu, salah satu alternatif yang dapat digunakan dalam pembelajaran menulis puisi yakni model pembelajaran kontekstual bermediakan facebook. Penelitian ini bertujuan mengetahui keefektifan penerapan model kontekstual dengan menggunakan media facebook dalam pembelajaran menulis puisi pada siswa kelas VIII SMP. Metode penelitian yang digunakan yaitu eksperimen kuasi. Data diperoleh melalui tes tertulis dan observasi. Hasil penelitian menunjukkan 1) rata-rata nilai siswa mengalami peningkatan dalam menulis puisi; 2) model kontekstual memudahkan siswa mengembangkan ide untuk menulis puisi sesuai dengan pengalaman mereka; 3) melalui media facebook, interaksi dalam pembelajaran terjalin dengan baik dan materi pembelajaran dapat tersampaikan dengan fleksibel; 4) karya puisi siswa sudah memuat imaji, diksi, dan majas secara tepat. Secara keseluruhan hasil penelitian ini menunjukkan model pembelajaran kontekstual dengan menggunakan media facebook secara efektif dapat meningkatkan kemampuan siswa dalam menulis puisi.
\end{abstract}

Kata kunci : Model pembelajaran kontekstual, media facebook, menulis puisi.

\section{A. PENDAHULUAN}

Keterampilan menulis puisi merupakan salah satu materi yang dipelajari di kelas VIII SMP. Dalam proses menciptakan karya sastra puisi ini, siswa masih mengalami hambatan karena terdapat berbagai aspek yang harus dikuasai. Hal ini seperti yang diungkapkan Gani (2014: 14) bahwa puisi merupakan ungkapan perasaan penulis yang diterjemahkan dalam susunan kata-kata dalam bentuk bait-bait berirama dan memiliki makna yang dalam. Dengan kata lain, puisi merupakan gambaran perasaan seorang. Agar ungkapan perasaan ini dapat dinikmati dan dipahami, siswa harus memiliki keterampilan dalam menulis puisi, seperti penguasaan terhadap diksi, rima, tipografi.

Berdasarkan hasil observasi di tiga sekolah di Kabupaten Cirebon, kemampuan 


\section{DEIKSIS - JURNAL PENDIDIKAN BAHASA DAN SASTRA INDONESIA}

menulis puisi siswa masih kurang sempurna, baik dilihat dari penyempurnaan kata, keindahan makna maupun dalam pemilihan diksi. Siswa masih tidak teratur dalam menulis puisi dan belum jelas makna khusus apa yang terkandung dalam puisi tersebut. Siswa hanya menulis puisi dengan apa yang ingin ditulis tanpa melihat bagaimana cara yang benar untuk menulis puisi. Faktor lain yang menjadi penghalang adalah kurangnya minat siswa dalam menulis puisi karena dianggap sebuah beban, cara penyampaian materi saat proses pembelajaran, penggunaan model yang tidak bervariatif artinya model yang digunakan tidak sesuai atau kurang cocok dengan mata pelajaran yang akan dipelajari dalam proses pembelajaran.

Penggunaan model dan media pembelajaran sangat berpengaruh penting. Dengan model dan media yang tepat, siswa pun mampu menguasai materi yang diajarkan oleh guru yang menjadi bukti keberhasilan dalam pencapaian kompetensi. Salah satu model pembelajaran yang dapat digunakan dalam pembelajaran sastra, khususnya menulis puisi adalah model kontekstual. Kontekstual merupakan model pembelajaran yang berkaitan langsung dengan kehidupan seseorang. Model kontekstual akan lebih mudah merangsang otak seseorang karena adanya keterkaitan pembelajaran dengan kehidupan seseorang. Johnson (Rusman, 2014: 189) memaparkan tujuan model pembelajaran kontekstual yaitu memperluas konteks pribadi siswa melalui pemberian pengalaman segar yang akan merangsang otak guna menjalin hubungan baru untuk menemukan makna.
Pembelajaran kontekstual didasarkan pada filosofi bahwa siswa mampu menyerap pelajaran apabila mereka dapat menangkap makna dari materi dan tugas-tugas sekolah yang diterima, jika mereka bisa mengaitkan informasi baru dengan pengetahuan dan pengalaman yang sudah dimiliki sebelumnya (Johnson, 2007:14). Dari penjelasan tersebut, dapat digarisbawahi bahwa dalam model siswa berperan utama. Dengan melibatkan atau menggabungkan beberapa metode atau strategi dalam proses pembelajarannya seperti inquiry, diskusi, dan masyarakat belajar, siswa mampu menggali atau menemukan ide-ide untuk menulis puisi dari pengalaman mereka sendiri tanpa adanya kesulitan karena dilibatkan langsung dengan kehidupan sehari-hari.

Apalagi didukung dengan media ICT, seperti facebook. Facebook menjadi media yang paling banyak digunakan untk mencurahkan perasaan, ide, dan pengalaman. Facebook merupakan situs web yang menyediakan sebuah kolom status untuk menuangkan segala sesuatu dengan bebas. Hal ini senada dengan Alba dan Stay (2009: 5) yang menjelaskan bahwa kolom status adalah tempat anda menuliskan apa saja yang anda inginkan. Dengan media ini, siswa dapat secara leluasa mengungkapkan perasaan mereka dan menuangkannya dalam bentuk puisi.

Studi ini didasari oleh beberapa hasil penelitian mengenai penggunaan model kontekstual dan media facebook, di antaranya dilakukan Rahayu (2012) yang membuktikan bahwa model pembelajaran kontekstual memberikan respons positif 


\section{DEIKSIS - JURNAL PENDIDIKAN BAHASA DAN SASTRA INDONESIA}

terhadap siswa dan hasil belajar siswa kelas XII SMKN 1 Denpasar tergolong baik sekali, yaitu dengan skor 85,5. Skor tersebut diperoleh berdasarkan penilaian terhadap tulisan siswa yang sesuai dengan ketentuan penilaian, seperti isi gagasan yang dikemukakan, organisasi isi, kosakata, pilihan kata, dan ejaan/mekanik. Penelitian lain dilakukan Ruqash (2014) yang menunjukkan media facebook dapat meningkatkan aktivitas dan keaktifan siswa dalam setiap proses pembelajaran dan hasil tes akhir juga menunjukkan adanya peningkatan nilai siswa.

Penelitian ini bertujuan mengetahui keefektifan penerapan model kontekstual bermediakan facebook dalam pembelajaran menulis puisi pada siswa kelas VIII SMPN 3 Sumber Kabupaten Cirebon tahun pelajaran 2016/2017; mendeskripsikan aktivitas siswa dalam pembelajaran; dan mendeskripsikan profil teks puisi pada siswa kelas VIII SMPN 3 Sumber dalam pembelajaran menulis puisi dengan menggunakan model kontekstual bermediakan facebook.

\section{B. KAJIAN TEORETIS}

\section{a. Pembelajaran Kontekstual}

Menurut Blanchard, dkk

(Komalasari 2014: 6), pembelajaran kontekstual merupakan konsep belajar dan mengajar yang membantu guru mengaitkan antara materi yang diajarkannya dengan situasi dunia nyata dan mendorong siswa membuat hubungan antara pengetahuan yang dimilikinya dengan penerapannya dalam kehidupan mereka sebagai anggota keluarga, warga, dan pekerja. Artinya, model pembelajaran kontekstual merupakan model yang berkaitan langsung dengan pengalaman siswa itu sendiri tanpa dipengaruhi oleh unsur atau pihak-pihak lainnya. Pengalaman siswa dalam model ini dijadikan sebagai titik utama dalam proses pembelajaran. Melalui kaitan langsung dengan pengalaman siswa, materi pembelajaran akan mudah tersampaikan kepada siswa. Siswa pun mudah memahami apa yang akan dipelajari.

Tujuan penggunaan model kontekstual yaitu untuk menguatkan, memperluas, dan menerapkan pengetahuan siswa serta keterampilan akademik mereka dari berbagai tatanan dalam sekolah maupun luar sekolah sehingga mereka dapat memecahkan masalah-masalah dunia nyata atau masalah-masalah yang disimulasikan (Trianto, 2009: 101). Artinya, model pembelajaran kontekstual bertujuan untuk motivasi siswa, menambah pengetahuan, dan memudahkan siswa dalam menerapkan materi dalam kehidupan nyata.

Aqib (2014: 6) merinci langkahlangkah penerapan model kontekstual sebagai berikut.

1) Mengembangkan pemikiran siswa dengan cara belajar secara mandiri.

Hal ini bertujuan agar siswa dapat mengonstruksi sendiri pengetahuan dan keterampilan barunya.

2) Menerapkan kegiatan inquiry dalam proses pembelajaran.

Proses inkuiri ini dapat dilakukan melalui beberapa langkah, yaitu: merumuskan masalah; mengajukan masalah; mengumpulkan data; dan menguji hipotesis berdasarkan data yang ditemukan.

3) Memberikan kesempatan kepada siswa untuk bertanya. 


\section{DEIKSIS - JURNAL PENDIDIKAN BAHASA DAN SASTRA INDONESIA}

Proses ini bertujuan menggali informasi tentang kemampuan siswa terkait dengan materi yang akan diberikan, membangun dan membimbing siswa untuk menemukan serta menyimpulkan segala sesuatu.

4) Komunitas belajar.

Dalam proses pembelajaran kontekstual akan tercipta sebuah konsep masyarakat belajar (Learning Community) sehingga hasil pembelajaran diperoleh melalui kerja sama dengan orang lain.

5) Menghadirkan model sebagai contoh proses pembelajaran.

Proses pembelajaran dengan memeragakan sesuatu sebagai contoh yang dapat ditiru oleh setiap siswa.

6) Melakukan refleksi pada akhir pertemuan

Proses mengulang kembali pengalaman yang telah dipelajari dengan cara mengurutkan kembali kejadian-kejadian atau peristiwa pembelajaran yang telah dilaluinya.

7) Melakukan penilaian.

Proses yang dilakukan oleh guru untuk mengumpulkan informasi tentang perkembangan belajar yang dilakukan siswa.

Ketujuh langkah tersebut dimulai dari langkah dasar dengan cara melibatkan langsung siswa untuk berpikir lebih kritis terhadap apa yang telah dilihat oleh pancaindranya. Setelah itu baru diikuti proses lainnya yang lebih tersurat seperti penerapan inquiry, proses tanya jawab, memunculkan masyarakat belajar, pemunculan model, refleksi, dan yang terakhir adalah penilaian. Langkah akhir memperlihatkan apakah keberhasilan model ini dalam materi sesuai atau malah sebaliknya. Jadi, langkah yang dilakukan dalam penerapan model pembelajaran kontekstual dimulai dari titik nol kemudian baru sedikit demi sedikit meningkat ke langkah-langkah yang lebih tinggi untuk menciptakan sebuah keberhasilan dalam proses pembelajaran.

\section{b. Facebook}

Facebook adalah sebuah situs web jejaring sosial populer yang diluncurkan pada 4 Februari 2004. Facebook sudah tidak asing lagi di Indonesia. Media sosial ini bertujuan untuk membuat penggunanya terhubung dengan pengguna lain, misalnya dengan cara berbagi ide, foto, video, status, dan sebagainya. Facebook merupakan tempat untuk meluapkan perasaan seseorang melalui kolom status. Dirgayuza (2009: 20) mengungkapkan status facebook adalah jawaban dari pertanyaan umum "apa yang sedang seseorang lakukan?". Dapat dikatakan bahwa status facebook memiliki arti dalam setiap apa yang dituliskan. Dengan kata lain, facebook merupakan tempat seseorang untuk meluapkan perasaan mereka tanpa adanya paksaan dari siapa pun. Berdasarkan hal tersebut, dapat dikatakan bahwa facebook adalah media yang tepat untuk digunakan penulis sebagai pelengkap dari model pembelajaran kontekstual, karena model pembelajaran kontekstual merupakan model yang mengumpulkan gagasangagasan kecil atau ide-ide kreatif siswa terhadap pengalaman siswa itu sendiri yang menurut siswa menarik dan semua itu akan dituangkan melalui media facebook. 


\section{DEIKSIS - JURNAL PENDIDIKAN BAHASA DAN SASTRA INDONESIA}

\section{c. Puisi}

Menulis puisi merupakan cara seseorang meluapkan emosi dan ke dalam sebuah tulisan. Seperti yang ditegaskan oleh Maulana (2012: 29) menulis puisi adalah kegiatan penuangan perasaan dan pemikiran seseorang dari hasil pengalaman hidupnya, baik fisik maupun metafisik yang tidak bisa dikarang-karang keberadaannya. Artinya, bahwa di dalam sebuah puisi terdapatnya sebuah kegiatan yang menyajikan apa yang pernah dialami atau dipikirkan dan dirasa oleh seseorang tanpa dibuat-buat atau direkayasa. Senada dengan pendapat tersebut, Sukino (2010: 136) mengatakan bahwa menulis puisi yaitu menuliskan segala kejadian yang ada. Singkatnya, apa yang dilihat oleh panca indra maka itulah yang akan dituliskan.

Ada beberapa hal yang harus diperhatikan dalam menulis puisi, di antaranya majas, diksi, dan imajinasi. Nadjua (2014: 18) menyatakan majas adalah bukan bahasa sebenarnya untuk melukiskan sesuatu baik itu benda mati maupun benda hidup dengan cara membandingkan, mempertentangkan, mempertautkan, atau mengulangi katanya. Artinya, majas merupakan bahasa yang sudah adanya perubahan untuk menggambarkan sesuatu yang dilihat oleh pancaindra dengan caracara tertentu. Nadjua (2014: 18) pula menyebutkan bahwa ada beberapa majas yang terlihat yang khusus dipelajari pada siswa SMP umumnya, di antaranya personifikasi, metafora, hiperbola, dan repetisi.
Wicaksono

$$
\text { (2014: }
$$

mengungkapkan bahwa diksi atau pilihan kata merupakan peranan penting dan utama. Diksi digunakan untuk mencapai keefektifan dalam penulisan suatu karya sastra khususnya puisi. Untuk mencapai diksi yang baik seorang penulis harus memahami secara lebih baik masalah kata dan makna yang terkandung. Bukan hanya itu seorang penulis harus memperluas dan mengaktifkan kosakata, mampu memilih kata yang tepat, kata yang sesuai dengan situasi yang dihadapinya, dan mengenali dengan baik macam corak gaya bahasa sesuai dengan tujuan penulisan. Penyair harus mampu pula menyeimbangkan kata-kata yang digunakan dengan tema yang diangkat dalam puisi. Adapun diksi yang digunakan untuk siswa SMP pada pembelajaran menulis puisi secara singkat menurut Keraf (2008: 89) meliputi denotasi dan konotasi.

Hal penting lain yaitu imajinasi dalam puisi. Imajinasi ialah gambaran perasaan seorang terhadap apa yang dilihat oleh pancaindra. Menurut Antara (Priyatni, 2012: 70), imajinasi merupakan pembayangan yang timbul sebagai akibat pembaca membaca atau mendengar sebuah puisi yang dibaca. Artinya, daya bayang atau pengimajian ini dianggap sebagai jiwanya puisi karena dengan disertai pengimajianlah sebuah puisi dapat dianggap lebih berjiwa dan lebih hidup. Misalnya daya bayang yang berupa penglihatan, pendengaran, perasaan, dan penciuman dalam sebuah puisi. 


\section{METODE PENELITIAN}

Metode yang digunakan dalam penelitian ini, yaitu metode eksperimen kuasi. Menurut Sugiyono (2015: 107), metode eksperimen dapat diartikan sebagai metode penelitian yang digunakan untuk mencari pengaruh perlakuan tertentu terhadap yang lain dalam kondisi yang terkendalikan. Artinya, metode tersebut adalah sebuah cara untuk memecahkan sebuah masalah dengan melihat hal apa yang memengaruhi subjek satu terhadap subjek lainnya.

Desain penelitian yang digunakan penulis yaitu nonequivalent control group design. Sugiyono (2015: 116) menyatakan bahwa desain penelitian ini hampir sama dengan desain control group pretest-posttest design yang merupakan bagian dari true eksperiment design. Artinya, dalam penelitian selain kelas eksperimen ada pula kelompok pembanding atau yang disebut kelas kontrol. Pada dasarnya desain tersebut pada kelas eksperimen dan kelas kontrol tidak dipilih secara random. Kelompok eksperimen diberikan perlakuan, sedangkan kelompok kontrol sebaliknya. Akan tetapi, keduanya dilakukan prauji dan paksa uji.

Penelitian ini dilakukan di kelas VIII SMP Negeri 3 Sumber sebanyak dua kelas. Kelas kontrol berjumlah 35 siswa dan kelas eksperimen berjumlah 35 siswa. Instrumen yang digunakan dalam penelitian ini adalah unjuk kerja untuk mengetahui kemampuan siswa dalam menulis puisi dan menguji efektiviitas model kontekstual dengan media facebook serta pedoman observasi untuk mendeskripsikan aktivitas siswa dalam pembelajaran.
Kegiatan dalam analisis data yaitu mengelompokkan data berdasarkan variabel dari seluruh responden, menyajikan data dari tiap variabel yang diteliti, melakukan perhitungan untuk menjawab rumusan masalah, dan melakukan penghitungan untuk menguji hipotesis yang telah diajukan. Teknik pengolahan data yang akan digunakan dalam penelitian ini adalah statistik deskriptif dan statistik uji t (t-test).

\section{PEMBAHASAN HASIL PENELITIAN}

\section{a. Efektivitas Model Pembelajaran Kontekstual Bermediakan Facebook dalam Pembelajaran Menulis Puisi}

Efektivitas model terlihat pada proses dan hasil tes yang dilakukan. Efektivitas proses pembelajaran terlihat pada tahapan berikut.

1) Pada tahapan mengembangkan pemikiran siswa secara mandiri, model pembelajaran kontekstual bermediakan facebook dapat meningkatkan semangat dan motivasi siswa ketika kegiatan pembelajaran dimulai. Siswa sangat antusias mengembangkan pemikiran mereka sesuai dengan apa yang mereka alami. Mereka merasa mudah dalam melakukannya karena mereka dekat dengan tahapan tersebut. Ide atau gagasan mereka temukan secara mudah tanpa adanya kesulitan.

2) Pada tahapan menerapkan kegiatan inquiry, siswa sedikit merasa kesulitan dalam menemukan masalah karena materi tersebut adalah materi yang baru sehingga mereka harus secara mandiri 


\section{DEIKSIS - JURNAL PENDIDIKAN BAHASA DAN SASTRA INDONESIA}

menemukan masalah apa saja yang ada pada contoh puisi yang diberikan oleh guru tersebut.

3) Pada tahapan memberikan kesempatan bertanya, siswa dengan sangat antusias menanyakan apa yang ingin ditanyakan. Banyak siswa yang aktif pada tahap ini karena pada tahap inilah siswa menemukan jawaban apa yang ingin mereka ketahui.

4) Pada tahapan komunitas belajar, diskusi dapat berjalan kondusif. Hal ini terlihat ketika siswa mulai mengumpulkan ide atau gagasan mereka satu sama lain dengan teman kelompoknya dan terlihat pula mereka memecahkan sebuah masalah dengan cara saling bertukar pikiran satu sama lainnya.

5) Pada tahapan menghadirkan model, siswa secara kreatif dan antusias membalas dua bait puisi yang berada pada group facebook. Siswa merasa mudah membalas puisi dari dua bait tersebut karena dua bait puisi tersebut masih berhubungan atau berkaitan langsung dengan pengalaman mereka sendiri.

6) Pada tahapan melakukan penilaian, siswa secara kreatif menilai hasil teman kelasnya dengan baik dan benar.

7) Pada tahapan melakukan refleksi, siswa secara senang melakukan tahapan akhir ini karena pada tahap ini siswa diminta mengemukakan kesan dalam proses pembelajaran dan mengemukakan hal apa yang sulit pada materi yang sudah dipelajari. Hal ini dilakukan dengan cara menulis secara kreatif, lalu memaparkannya di depan kelas menggunakan kertas asturo atau karton dengan seunik mungkin.

Berdasarkan hasil tes pembelajaran menulis puisi dengan menggunakan model kontekstual bermediakan facebook dapat dilihat perbedaan secara signifikan terhadap kemampuan menulis puisi. Berdasarkan data hasil tes awal siswa kelas eksperimen diperoleh jumlah nilai 1883 dengan nilai rata-rata 53,8 dan jumlah nilai tes akhir adalah 2576 dengan nilai rata-rata 73,6. Sementara itu, hasil tes awal siswa kelas kontrol diperoleh jumlah nilai 1729 dengan nilai rata-rata 49,4 dan jumlah nilai tes akhir 2345 dengan nilai rata-rata 67. Nilai tes akhir pembelajaran menulis puisi di kelas eksperimen lebih baik dibandingkan dengan kelas kontrol. Selain itu, hasil perhitungan uji-t' juga membuktikan bahwa $t_{\text {hitung }}>t_{\text {tabel }}$ atau 2,11>1,995 pada taraf signifikan 5\%. Hal ini berarti $\mathrm{H}_{0}$ ditolak dan $\mathrm{H}_{1}$ diterima karena dalam pembelajaran menulis puisi, siswa dapat dengan mudah menulis puisi sesuai dengan pengalaman mereka sendiri dengan tema bebas. Dengan demikian, penerapan model pembelajaran kontekstual bermediakan facebook dalam pembelajaran menulis puisi pada siswa kelas VIII SMP Negeri 3 Sumber efektif.

\section{b. Aktivitas Siswa dalam Pembelajaran Menulis Puisi dengan Menggunakan Model Pembelajaran Kontekstual Bermediakan Facebook}

Berdasarkan pengamatan yang penulis lakukan bahwa aktivitas pembelajaran yang dilakukan siswa cukup baik karena dapat mengikuti tahapantahapan kegiatan pembelajaran yang 


\section{DEIKSIS - JURNAL PENDIDIKAN BAHASA DAN SASTRA INDONESIA}

diberikan oleh guru. Penulis dapat dimenyatakan bahwa model pembelajaran kontekstual bermediakan facebook dapat meningkatkan kemampuan berpikir siswa. Siswa dapat lebih mudah dalam mencari ide ataupun gagasan. Di samping itu, mereka dapat percaya diri ketika berdiskusi bertukar pendapat memecahkan permasalahan, dan meningkatkan kemampuan menulis. Keaktifan siswa ini terlihat pada setiap tahapan model kontekstual sesuai dengan teori Aqib (2013: 6) sebagai berikut.

1) Tahap pertama mengembangkan pemikiran peserta didik secara mandiri. Pada tahapan ini siswa menyebutkan kejadian-kejadian yang berkesan di hati mereka dalam kehidupan sehari-hari; siswa menumpahkan perasaan-perasaan mereka saat menyebutkan kejadian tersebut melalui tulisan; dan siswa mengidentifikasi kejadian yang telah dialaminya. Tahapan ini berjalan sesuai dengan teori pada saat penerapan siswa dengan mudah menumpahkan perasaanperasaan mereka tanpa adanya kesulitan yang terlihat dalam wajah mereka. Siswa menumpahkan ide-idenya sesuai dengan apa yang mereka pikirkan dan apa yang mereka pernah alami. Siswa belajar dengan antusias karena salah satu alasannya materi yang mereka pelajari dekat dengan mereka.

2) Tahap kedua menerapkan kegiatan inquiry dalam proses pembelajaran. Pada tahapan ini siswa mencoba memahami dan mengamati contoh puisi. Siswa menemukan kata-kata yang sulit dipahami dan dimengerti serta menemukan kekurangan dalam puisi tersebut. Lalu, siswa mencoba mengartikan inti isi puisi. Sementara itu, pada saat penerapan tahapan kedua siswa sedikit merasa kesulitan karena mereka harus menemukan hal-hal yang kurang dalam contoh puisi yang guru berikan sesuai dengan pemahaman teori puisi yang siswa kuasai. Jadi, pada tahap kedua ini siswa begitu bekerja keras dalam mengerjakan tugas yang diberikan oleh guru. Akan tetapi pada akhirnya, siswa mampu lama kelamaan mengikuti jalur yang ditunjukkan oleh guru.

3) Tahap ketiga memberikan kesempatan kepada siswa untuk bertanya. Pada tahapan ini siswa bertanya tentang makna dari kata-kata yang sulit untuk mereka pahami dalam puisi tersebut. Siswa bertanya tentang unsur-unsur ada dalam sebuah puisi dan mengomentari secara detail tentang puisi tersebut. Pada tahap ketiga ini, siswa sejalan dengan apa yang diterapkan dalam teori. Siswa begitu antusias untuk bertanya kepada guru, banyak pertanyaan yang muncul dari yang sederhana sampai pertanyaan yang sulit. Siswa begitu kritis menanyakan hal-hal yang kurang dimengerti mereka. Bagi mereka tahapan ini merupakan kesempatan emas untuk menemukan ilmu baru yang belum mereka ketahui. Hampir satu kelas aktif mengajukan pertanyaan.

4) Tahap keempat komunitas belajar. Pada tahapan ini siswa membentuk kelompok dan saling bertukar pikiran untuk menemukan sebuah ide atau gagasan serta mereka pun memecahkan sebuah 


\section{DEIKSIS - JURNAL PENDIDIKAN BAHASA DAN SASTRA INDONESIA}

masalah yang ditemukan. Saat tahapan keempat dalam pembelajaran di kelas, siswa secara kondusif melakukan kerja kelompok baik dalam pembentukan maupun dalam mengerjakan. Siswa dengan kreatif dan komunikatif menyampaikan gagasan-gagasan mereka dalam memecahkan masalah bersama teman kelompoknya.

5) Tahap kelima menghadirkan model. Pada tahapan ini siswa mengomentari dua bait puisi yang berada pada group facebook dengan baik dan benar. Dalam tahapan kelima ini, siswa begitu antusias mengomentari dua bait puisi yang guru berikan. Mereka dengan mudah membalas dua bait puisi tersebut karena tema dua bait puisi tersebut tidak jauh dari kehidupan mereka. Jawaban yang siswa berikan tidak melenceng dari jalur (tema) melainkan jawaban yang mereka berikan sejalan dengan tema yang guru berikan.

6) Tahap keenam melakukan penilaian. Pada tahapan ini siswa menilai hasil kerja teman kelompoknya dengan jujur. Pada saat penerapan di kelas siswa dengan mudah dan jujur melakukan tahapan ini. Siswa menilai teman kelompoknya sesuai dengan apa yang mereka pelajari tanpa adanya unsur kepaksaan ataupun kecurangan.

7) Tahap ketujuh melakukan refleksi. Pada tahapan ini siswa melakukan refleksi terhadap kegiatan pembelajaran yang telah dilaksanakan. Pada tahapan terakhir saat penerapan di kelas, siswa begitu bergembira dan antusias karena pada tahap ini siswa secara bebas menuangkan apa yang mereka dapatkan selama belajar dan mereka menempelkan hasil karya tulis di dalam kelas. Antusias tergambar jelas di wajah mereka karena merasa sedang melakukan curhat (curahan hati) dalam proses pembelajaran.

\section{c. Profil Karya Tulis Puisi Siswa}

Profil siswa kelas VIII SMP Negeri 3 Sumber tahun pelajaran 2016/2017 menunjukkan bahwa tulisan siswa selama proses pembelajaran menulis puisi sudah cukup bagus. Berdasarkan indikator pembelajaran menulis puisi yaitu mampu mengembangkan imaji dengan tepat; mampu menulis puisi dengan menggunakan pilihan kata yang tepat; mampu menggunakan majas metafora, hiperbola, personifikasi, dan majas repitisi dengan tepat dalam menulis puisi; dan teori puisi yang dipelajari siswa dalam model pembelajaran kontekstual bermediakan facebook dapat meningkatkan kemampuan menulis siswa.

Hal ini dapat dilihat dari hasil tulisan siswa yaitu pada segi ketepatan menggunakan imaji. Siswa sudah mampu mengembangkan imaji mereka dengan tepat. Siswa dapat menuliskan sesuatu yang mereka lihat atau mereka rasakan dengan menciptakan kata yang indah sesuai dengan pancaindera mereka. Dari hasil analisis yang dilakukan, siswa sudah memunculkan diksi yang benar dalam tulisan mereka sesuai dengan judul ataupun tema yang mereka pilih walaupun masih ada sedikit kesalahan dalam penempatannya karena mereka kesulitan dalam memilih diksi yang tepat sesuai dengan tema dan judul yang mereka 


\section{DEIKSIS - JURNAL PENDIDIKAN BAHASA DAN SASTRA INDONESIA}

tentukan sendiri. Siswa hanya senang menggali kata demi kata yang mereka temukan untuk ditulis tanpa melihat tema dan judul yang mereka pilih. Pada segi kemampuan menggunakan majas, siswa sudah mampu menggunakan majas dengan baik dan benar. Majas yang mereka gunakan sudah mampu melukiskan suatu benda, menimbulkan konotasi tertentu, dan mereka mampu membuat pembaca merasakan apa yang mereka rasakan pada tulisan yang mereka buat. Namun, ada beberapa siswa yang masih kesulitan dalam penggunaan majasnya. Majas yang mereka gunakan masih kacau dan tidak ada arah tujuannya.

Berdasarkan hasil penelitian yang telah dilakukan, peneliti menemukan hal-hal berikut ini saat penerapan model pembelajaran kontekstual bermediakan facebook dalam pembelajaran menulis puisi pada siswa kelas VIII SMP Negeri 3 Sumber.

1) Model kontekstual bermediakan facebook sangat bagus untuk diterapkan dalam pembelajaran menulis puisi karena dalam model pembelajaran kontekstual siswa akan dekat dengan materi yang akan dipelajari. Semua yang akan dipelajari oleh siswa berhubungan langsung dengan siswa itu sendiri. Guru akan mudah dalam menyampaikan materi dan siswa pun tidak akan merasa kesulitan dalam menerima materi.

2) Model pembelajaran kontekstual memang bukanlah model yang sempurna. Setiap model pasti memiliki kekurangan, begitu juga dengan model kontekstual. Jika menggunakan model kontekstual seorang guru harus sabar dalam menerapkan model ini karena model ini berhubungan langsung dengan pengalaman siswa itu sendiri. Terkadang siswa merasa buntu dengan apa yang mereka alami. Tugas kita sebagai guru adalah membuka kunci pemikiran mereka dengan cara menanyakan seperti apa saja yang pernah dilakukan dan bagaimana perasaan saat melakukan sesuatu baik yang disenangi maupun yang tidak senangi. Butuh waktu yang ekstrasabar dalam melakukan penerapan model ini, karena model ini pula membutuhkan waktu yang tidak sedikit.

3) Menggunakan media facebook dalam pembelajaran sangat menguntungkan bagi pembelajaran karena seorang guru terbantu dalam menyampaikan materi. Materi dapat disampaikan secara langsung dan tidak langsung (kapan saja). Bukan hanya itu kedekatan siswa dengan guru pun akan terjalin. Siswa dapat bertanya kapan saja dengan guru juga dengan siswa lainnya, diskusi akan selalu terjadi dan materi cepat tersampaikan. Siswa merasa senang dan semangat untuk belajar karena pembelajaran menjadi tidak membosankan.

4) Media facebook bukan media yang media sempurna. Kekurangan media ini yaitu saat penerapan ditemukan ada siswa yang tidak memiliki koneksi internet, akhirnya dia tidak bisa mengikuti pembelajaran. Siswa hanya mendapatkan pembelajaran di dalam kelas saja tanpa mengikuti pembelajaran 


\section{DEIKSIS - JURNAL PENDIDIKAN BAHASA DAN SASTRA INDONESIA}

yang menggunakan media facebook. Oleh sebab itu, untuk mengatasi semuanya guru menyediakan jaringan internet di dalam kelas.

5. Pada media facebook kekurangan yang terlihat dalam proses pembelajaran bukan hanya dalam koneksi internet, melainkan apabila seorang guru menggunakan media ini akan terlihat siswa yang sibuk sendiri dengan smartphone mereka, tidak adanya interaksi baik dengan guru maupun dengan teman sekelasnya. Interaksi terjadi hanya dengan smartphone. Oleh sebab itu, untuk mengatasi semuanya seorang guru harus sepintar mungkin menempatkan media ini pada tahap manakah yang tepat dan cocok digunakan. Bukan hanya itu, guru pula harus lebih bekerja keras dalam mengontrol proses pembelajaran.

\section{E. SIMPULAN}

Berdasarkan hasil penelitian dan pembahasan yang penulis lakukan, dapat disimpulkan sebagai berikut.

a. Keefektifan penerapan model pembelajaran kontekstual bermediakan facebook dapat ditunjukan melalui hasil siswa kelas eksperimen. Nilai tes akhir pembelajaran menulis puisi di kelas eksperimen lebih baik dibandingkan dengan kelas kontrol. Selain itu, hasil perhitungan uji-t' juga membuktikan bahwa $t_{\text {hitung }}>t_{\text {tabel }}$ atau 2,11 $>1,995$ pada taraf signifikan 5\%. Hal ini berarti dalam pembelajaran menulis puisi siswa dapat dengan mudah menulis puisi sesuai dengan pengalaman mereka sendiri dengan tema bebas. Dengan demikian, penerapan model pembelajaran kontekstual bermediakan facebook dalam pembelajaran menulis puisi pada siswa kelas VIII SMP Negeri 3 Sumber efektif.

b. Berdasarkan hasil pengamatan yang dilakukan selama proses pembelajaran, terbukti bahwa penerapan model kontekstual bermediakan facebook dalam pembelajaran menulis puisi dapat membuat siswa lebih aktif di kelas. Keaktifan tersebut terlihat dengan aktivitas siswa yang bersemangat, lebih kreatif, dapat memecahkan masalah lebih cepat, dan dapat menuangkan pemikiran mereka ke dalam tulisan. Berdasarkan hasil perhitungan persentase keaktifan siswa, diperoleh hasil sebanyak 95\% dan berada pada kategori sangat baik.

c. Hasil analisis tulisan siswa kelas VIII SMP Negeri 3 Sumber dalam pembelajaran menulis puisi yaitu dilihat dari segi ketepatan menggunakan imaji; ketepatan menggunakan diksi; dan ketepatan menggunakan majas dapat dikatakan cukup baik. Hal ini terlihat pada hasil tulisan siswa tes akhir di kelas eksperimen yang sudah cukup memenuhi krtiteria penilaian yaitu diperoleh jumlah nilai tes akhir adalah 2576 dengan nilai rata-rata 73,6.

\section{F. DAFTAR PUSTAKA}

Alba, Jonan dan Jesse Stay. 2009. Facebook Super Mudah. Yogyakarta: Venus. 


\section{DEIKSIS - JURNAL PENDIDIKAN BAHASA DAN SASTRA INDONESIA}

Aqib, Z. 2014. Model-model, Media, dan Strategi Pembelajaran Kontekstual (Inovatif). Bandung: Yrama Widya.

Dirgayuza, S. 2009. Panduan Praktis Mengoptimalkan Facebook. Jakarta: PT Trans Media.

Gani, E. 2014. Kiat Pembacaan Puisi Teori dan Penerapan. Bandung: Pustaka Reka Cipta.

Johnson, Elaine. 2011. Contextual Teaching and Learning. Bandung: Kaifa.

Keraf, Gorys. 2008. Diksi dan Gaya Bahasa. Jakarta: PT Gramedia Pustaka Utama.

Komalasari, Kokom. 2014. Pembelajaran Kontekstual. Bandung: PT Refika Aditama.

Maulana, S.F. 2012. Apresiasi dan Proses Kreatif Menulis Puisi. Bandung:Nuansa.

Nadjua. 2014. Buku Pintar Puisi dan Pantun. Surabaya: Triana Media.

Priyatni, E. T. (2012). Membaca Sastra dengan Ancangan Literasi Kritis. Jakarta: PT Bumi Aksara.

Ruqash, M.Y. 2014. Penggunaan Metode Curah Gagasan Bermediakan Facebook dalam Pembelajaran Menulis Puisi pada Siswa Kelas X Man Cirebon 1. Vol 1 number 10 (10 April 2016).

Rahayu, Sri. 2012. Penerapan Model Pembelajaran Kontekstual dalam Pembelajaran Menulis pada Siswa Kelas XII SMKN 1 Denpasar. Vol 1 number 14. Diambil dari: http://www.jurnalkontekstual.com. (07 April 016).

Sugiyono. 2015. Metode Penelitian
Kuantitatif, Kualitatif dan $R \& D$. Bandung: Alfabeta.

Sugiyono. 2015. Metode Penelitian Pendidikan. Bandung:Alfabeta.

Sukino. 2010. Menulis itu Mudah. Yogyakarta. Pustaka Populer.

Trianto. 2007. Model-model Pembelajaran Inovatif BerorientasiKonstruktivisik. Jakarta: Prestasi Pustaka.

Wicaksono, M. A. 2014. Menulis Kreatif Sastra dan Beberapa Model Pembelajarannya. Yogyakarata: Garudhawacana. 